\title{
Cytokine gene polymorphisms in Greek patients with severe asthma
}

\author{
Despina Papakosta ${ }^{1 *}$, Eirini Kontakioti ${ }^{2}$, Kalliopi Domvri ${ }^{2}$, Evagelia Fouka ${ }^{2}$, Despina loannidou ${ }^{2}$, \\ Konstantinos Porpodis ${ }^{2}$, Michail Daniilidis ${ }^{3}$, Konstantinos Zarogoulidis $^{2}$ \\ From 2nd International Severe Asthma Forum (ISAF) \\ Athens, Greece. 13-15 November 2014
}

\section{Background}

The aim of the present study was to investigate the cytokine genetic profile in patients with severe asthma.

\section{Method}

The study population consisted of 52 patients, 30 with allergic asthma, mean age $35,2 \pm 14,51$ years (Group A), 22 patients with non-allergic asthma, mean age 47,1 $\pm 16,3$ years (Group B) and 21 healthy controls, mean age 36,6 $\pm 10,5$ years (Group C). 29 patients had mild, 10 moderate and 12 severe asthma. For the immunogenetic study DNA was extracted from the patients' peripheral blood samples. Determination of gene polymorphisms were performed by PCR using the INVITROGEN kit.

\section{Results}

Analysis of IL-1 polymorphisms and in particular IL-1 $\beta$ (+3962) showed statistically significant differences between Group A-B ( $\mathrm{p}=0.029)$ and Group B-C ( $=0.024)$ respectively. Analysis of IL4 -1098 polymorphisms showed an increased frequency of guanine in Group A $(\mathrm{p}=0.036)$ when compared to Group C whereas for IL4 -590, CC genotype showed an increased frequency in Group $\mathrm{C}$ and $\mathrm{C} / \mathrm{T}$ in Group A ( $\mathrm{p}=0.003$ ), suggesting possible association between thymine and risk of asthma development. Regarding IL-10 the diplotype GCC/ACC was more frequent in Group A when compared with Group $(\mathrm{p}=0,038)$. The TGF- $\beta 1$ diplotype CG/CC showed increased frequencies in comparison with Group B and Group C ( $\mathrm{p}=0,041 \kappa \alpha$ । $\mathrm{p}=0,012 \alpha v \tau i \sigma \tau o l \chi \alpha)$. Analysis of TNF $\alpha-238$ in G/G and $\mathrm{A} / \mathrm{G}$ genotypes showed statistically significant differences between the Group A-C, $(\mathrm{p}=0.008)$ and Group B-C $(p=0.001)$. $G / G$ showed an increased frequency in Group

\footnotetext{
Pulmonary Department Aristotle University of Thessaloniki, Thessaloniki, Greece

Full list of author information is available at the end of the article
}

$\mathrm{C}$ and $\mathrm{A} / \mathrm{G}$ in Groups A and B. Besides, analysis of IFN- $\gamma$ showed that the AA genotype was associated with Group $\mathrm{C}$ whereas the genotype AT was associated with risk of development of non allergic asthma $(\mathrm{p}=0,006)$. Regarding asthma severity, severe asthma compared with mild asthma, was associated with the genotype C/T of IL- $1 \alpha$ and IL1 $\beta+3962(\mathrm{p}=0.019 \kappa \alpha \iota \mathrm{p}=0.025$ respectively), with the IL-4TTT/GCC diplotype, with the IL10GCC/ACC $\kappa \alpha$ । IL10GCC/ATA diplotypes ( $\mathrm{p}=0.045)$ and with the IL$12 \mathrm{AC}$ genotype $((\mathrm{p}=0.046)$.

\section{Authors' details}

'Pulmonary Department Aristotle University of Thessaloniki, Thessaloniki, Greece. ${ }^{2}$ Aristotle University of Thessaloniki, Pulmonary Department, Thessaloniki, Greece. ${ }^{3}$ Aristotle University of Thessaloniki, 1st Department of Internal Medicine, Thessaloniki, Greece.

\section{Published: 23 March 2015}

\section{doi:10.1186/2045-7022-5-S2-P9}

Cite this article as: Papakosta et al: Cytokine gene polymorphisms in Greek patients with severe asthma. Clinical and Translational Allergy 2015 5(Suppl 2):P9.

Submit your next manuscript to BioMed Central and take full advantage of:

- Convenient online submission

- Thorough peer review

- No space constraints or color figure charges

- Immediate publication on acceptance

- Inclusion in PubMed, CAS, Scopus and Google Scholar

- Research which is freely available for redistribution 